\title{
The syntax of direct quotes with special reference to Spanish and English
}

\section{Margarita Suñer}

Published online: 2 October 2007

(C) Springer Science + Business Media B.V. 2007

\section{Erratum to: Nat Lang Linguist Theory (2000) 18:525-578 \\ DOI 10.1023/A:1006474231809}

The name of the author is misspelled in the online version of the article. The author's correct name is Margarita Suñer.

The online version of the original article can be found under doi:10.1023/A:1006474231809.

M. Suñer $(\bowtie)$

Linguistics-Morrill Hall, Cornell University, Ithaca, NY 14853, USA

e-mail:ms24@cornell.edu 